\title{
MAP Kinase-Activating Death Domain Protein
}

National Cancer Institute

\section{Source}

National Cancer Institute. MAP Kinase-Activating Death Domain Protein. NCI Thesaurus. Code C26479.

MAP kinase-activating death domain protein (1647 aa, $183 \mathrm{kDa}$ ) is encoded by the human MADD gene. This protein is involved in the regulation of both guanine nucleotide exchange and cellular proliferation. 